\title{
ЛІТЕРАТУРОЗНАВСТВО
}

\section{НОВЕЛІСТИКА ВАСИЛЯ ГАБОРА: ТРАДИЦІї Й НОВАТОРСТВО}

\author{
НАТАЛІЯ ДАШКО \\ Дніпровський національний університет імені Олеся Гончара, Дніпро - Україна \\ dashko_ns@ukr.net; ORCID: 0000-0002-5415-4983 \\ NOWELISTYKA WASYLA GABORA: \\ TRADYCJA I NOWATORSTWO
}

\author{
NATALIA DASZKO \\ Dnieprzański Uniwersytet Narodowy imienia Ołesia Honczara, Dniepr — Ukraina
}

STRESZCZENIE. Artykuł poświęcony jest twórczości W. Gabora w kontekście zróżnicowanej gatunkowo i stylistycznie współczesnej ukraińskiej nowelistyki. Celem artykułu jest ukazanie twórczości wspomnianego pisarza w dialektyce tradycji i nowatorstwa. W wyniku dogłębnej analizy można dojść do wniosku, że W. Gabor kontynuuje gatunek klasycznej noweli i jednocześnie eksperymentuje, wprowadzając innowacje nie tylko w obrębie formy, ale i treści. Wczesne utwory prozaika wykazują cechy poetyki modernistycznej. Silnym dramatyzmem i lakonicznością w duchu W. Stefanyka wyróżniają się nowele Щоб не бив бубон, Звір, Швони (tom Книга екзотичних снів та реальних подій), w których realizowane są główne postulaty ekspresjonizmu — konfrontacja życia i śmierci, tragiczny światopogląd, psychologizm, ważna rola szczegółu artystycznego. W nowelach ze zbioru Про щзо думає людина pojawiają się cechy impresjonizmu łączące W. Gabora z M. Kociubynskim. Jednocześnie można wyróżnić w powyższym tomie główne cechy współczesnej noweli modyfikowanej, gdy działania wewnętrzne bohaterów wychodzą na plan pierwszy, podobnie jak pogłębiona asocjatywność, metaforyczność, wyobrażenia. Ponadto w stylu W. Gabora można wyróżnić zarówno elementy realistyczne, jak i romantyczne, których połączenie stanowi podstawę fantastycznego realizmu pisarza (nowela Поминки).

Słowa kluczowe: nowela, ekspresjonizm, impresjonizm, psychologizm, szczegół artystyczny, realizm fantastyczny 


\title{
VASYL GABOR’S NOVELS: TRADITIONS AND INNOVATIONS
}

\author{
NATALIA DASHKO \\ Dnipro National Uniwersity named after Oles Gonchar, Dnipro — Ukraine
}

\begin{abstract}
The article presents an attempt at interpreting Gabor's works to disclose some ambiguities. The investigation is carried out within the research framework of modern Ukrainian novel varied by genre aspects and stylistic features. This determines the topicality of the paper, which aims to identify traditions and innovations in the writer's novels. The investigation leads to the conclusion that V. Gabor has contributed to further development of a classical novel genre and simultaneously has ventured to experiment. He recreates not only the form, but also the content. Works of the novelist are primarily marked with the modernist poetics features. Short stories Shchob ne byv bubon, Zvir, Shvonts (the collection Knyha ekzotychnykh sniv ta realnykh podii) are dramatic and laconic in a Stefanyk style. The main dilemma of expressionism is realized in those novels - the confrontation of life and death, the tragedy of mental outlook, psychologism, important functional role of artistic detail. In the novels of the collection Pro shcho dumaie liudyna there are signs of impressionism, which brings V. Gabor to M. Kotsiubynskyi. Simultaneously key features of the modern modified novel appear when the internal action becomes the main one with profound associativity, metaphors, figures of speech highlighted. In addition, the components of Gabor's style are both realism and romanticism, the combination of which becomes the basis for the fantastic realism (novel Pomynky).
\end{abstract}

Key words: novel, expressionism, impressionism, psychologism, artistic detail, fantastic realism

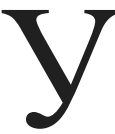

сучасній українській літературі одним 3 провідних жанрів $є$ новела. Коло письменників-новелістів досить широке: серед них Н. Бічуя, В. Габор, С. Грабар, В. Даниленко, С. Кононенко, Б. Мельничук, В. Назаренко, Г. Пагутяк, Л. Пономаренко, В. Портяк, А. Содомора, Л. Таран, Г. Тарасюк, Л. Тарнашинська, І. Роздобудько та ін. Таке активне зацікавлення новелою пояснюється тим, що вона, як жодний інший жанр, віддзеркалює сучасність і ті зміни, що відбуваються в суспільстві й свідомості людей, дає змогу максимально заглибитися у внутрішній світ героїв. Проте й сама новела зазнає певних трансформацій і репрезентована значною кількістю жанрово-стильових модифікацій, серед яких назвемо магічну (В. Габор), неоготичну, гротескно-іронічну (В. Даниленко), філософсько-інтелектуальну (В. Назаренко) новели тощо.

Серед здобутків сучасної української новелістики особливе місце посідає творчість В. Габора. Перу автора належать лише дві (абсолютно різні за жанрово-стильовими особливостями) збірки: Книга екзотичних снів та реальних подій і Про щзо думає людина: Візї та невигадані історії. Перша з них писалася впродовж двадцяти років. Такий довготривалий процес роботи над збіркою письменник пояснив просто: „Я пишу виключно новели, а це дуже 
специфічний жанр, який вимагає колосальної концентрації енергії й емоцій та миттєвого вибуху. А в подібному стані людина не може знаходитися постійно, тому новелісти й пишуть так мало" [Габор 2010: 111-112].

Книга екзотичних снів та реальних подій побачила світ 1999 р. (потім ії ще двічі перевидали) і відразу опинилася й продовжує залишатися в центрі наукових зацікавлень літературознавців, кожен з яких знаходить у ній щось своє. Твори збірки розглядають як крізь призму традиції новелістичного жанру, порівнюючи новели Габора й Стефаника [Слободян 1999: 8-18], так і новаторства, зазначаючи, що новели В. Габора - це яскравий зразок сучасної української магічної новели [Мельник 1998: 46-51]. Досліджуючи новелістику В. Габора в контексті світової літератури, А. Горнятко-Шумилович ставить в один ряд його новели й новели аргентинського письменника $\mathrm{X}$. Кортасара й відзначає, що обидва автори дотримуються принцииу лаконічності новелістичного жанру (причому дослідниця справедливо наголошує на тому, що у В. Габора проза навіть більш лаконічна), ,характер фантастичного, своєрідна оніричність, балансування на межі сну й дійсності, подібність мотивів тощо" [Горнятко-Шумилович 2014: 39-49].

Збірка Про що думає людина, до якої В. Габор, за його словами, ішов ,майже п'ятнадцять літ, збираючи для неї нові слова, образи і враження" [Габор 2012: 7], народилася буквально за декілька місяців [Габор 2012: 8], за жанром і стилем відрізняється від попередньої. Свій творчий задум письменник розкриває в Слові до читача, уміщеному як передмова до збірки: „...довкола відбувається так багато цікавих подій, і живе так багато людей із дивними й сумними долями, що в мене з'явилося непереборне бажання розповідати саме про них. Однак для цього потребував інших слів, іншої тональності й іншого [...] виміру мови" [Габор 2012: 7]. Тож на перший план зображення виходять людина і світ, свідченням чого $є$ назви творів Світ людини в кімнаті, Світ людини біля будинку, Світ, який зникає та ін., а також внутрішній світ людини з ії думками й переживаннями, що підтверджує поетика назви Про щзо думає людина. В одному з інтерв'ю з нагоди виходу збірки В. Габор зазначив, що „хотів написати невелику за обсягом книгу, в якій був би великий світ" [Таран 2018]. Письменнику це вдалося: внутрішній світ людини й світ навколо неї поєдналися в один великий світ.

Жанр творів збірки Про що думає людина В. Габор визначає як новели, хоча дослідники зауважують, що ці твори „не вкладаються у звичайну жанрову класифікацію, це роздуми, оповіді” [Неборак 2018], тому „важко однозначно визначити жанр" - новели це чи етюди, але це не має значення, головне „Полягає в тому, що цю прозу читаєш з неослабним інтересом” [Погорецький 2018]. Власне, сам письменник зізнається, що після Книги екзотичних снів та реальних подій йому було нецікаво. Він боявся, щоб друга збірка не вийшла подібною до першої, тому не мав на меті „писати оповідання чи новели, стро- 
го дотримуючись вимог жанру та вигадуючи нових героїв, тому зупинив свій вибір на улюбленому японському жанрі дзуйхіцу — вільному «слідуванню пензлю», чи пак — на асоціативному письмі” [Габор 2012: 7]. Цей жанр дав змогу В. Габору в довільній формі записати власні переживання, враження, досвід тощо. Очевидно, те, що термін джуйхіиу часто тлумачать як 'есе' або ‘записки' [Культура Японії 2019], дає підстави дослідникам уважати твори збірки Про щуо думає людина есеїстикою.

Зважаючи на таку неоднозначність і дискусійність в інтерпретації новелістичного доробку В. Габора, уважаємо, що обраний авторкою аспект дослідження $є$ актуальним.

Насамперед зазначмо, що новели В. Габора досить різнопланові. Зокрема, у Книзі екзотичних снів та реальних подій, як видається, можна виділити кілька жанрових різновидів новели: реалістичну (Голос пізнього ивіту); реалістично-комічну (Переговори, Любаска, Зимове весілля); філософську (Втрата сутності, Драбина до небес, Сходи вгору і вниз, Вакуум), хоча щодо філософічності, то це невід'ємна риса всіх новел письменника; містично-реалістичну (Ніч, щзо ховає усі дороги, Поминки); магічну (У кнайпі пані Рузі, Полювання у втраченому просторі, Осика в Гетсиманському саду, Дорога до Вічного міста - твори, де дійсне та уявне існують поряд, де органічно поєднуються різні світогляди: реалістичний, міфологічний, релігійний); психологічну (Самотні жінки, Звір) тощо. У новелах збірки яскраво виражені ознаки експресіонізму (Щоб не бив бубон, Звір, Швони), що споріднює їх 3 новелістикою В. Стефаника.

Новела Щоб не бив бубон - невеликий за обсягом (усього дві сторінки тексту) твір з абсолютно новелістичною формою зображення трагічної дійсності, в основі якого - розповідь про незвичайну подію з несподіваним фіналом. Узято один момент із життя безіменної героїні та їі дітей — голодомор (точної часової вказівки немає) і покарання двох злодіїв, які вкрали з млина два мішки борошна, тобто тема голодомору розгортається в контексті вибору людини в екстремальній ситуації, коли до вибору спонукають зовнішні обставини: два чоловіки стають злодіями, щоб їхні родини не померли з голоду. За скоєний злочин жандарми цілий день водять чоловіків селом і жорстоко їх б'ють під гупання бубна. Звук бубна, до якого додається людське гойкання, сповіщає, що сталося щось страшне й підсилює загострене сприйняття трагічної дійсності.

Новела починається словами: Діти просили їсти, а вона не мала що дати - художня деталь, що кілька разів повторюється й стає визначальною у вчинку героїні. Автор удається до натуралістичного зображення голодних дітей, що цілком у дусі В. Стефаника: [...] роздягнені діти згрудилися посеред хати навколо табуретки й одне перед одним лизали ї̈ середину, просякнуту запахом рибини. Очі їх горіли, а голі, худі тільия і руки так поперепліталися, 
щзо нагадали їй кубло змій, котре треба вбити [Габор 2009: 146]. Така експресіоністична образність створює гнітючий настрій новели. За канонами новелістичного жанру увага автора сконцентрована й на змалюванні внутрішніх станів героїні: з острахом глянула... Скрикнула. Злякалася. I дітей, $i$ своїх думок [Габор 2009: 146], - де всі речення сконденсовані, немає жодного зайвого слова.

Трагічна розв'язка (Нам мама принесла півмішка муки, а сама втопилася y річщі [Габор 2009: 147]) відразу робить зрозумілою поетику назви Щоб не бив бубон. У такому зображенні актуалізується ключова для експресіонізму проблема провини й кари. Мати добровільно карає себе - чинить самогубство, щоб уникнути іншої кари, а можливо, щоб так очистити душу.

Новела Звір просякнута нервовою емоційністю й трагічним світовідчуттям. Твір психологічно напружений і глибинний за характером проникнення в таїну душі головної героїні Марії. Перед читачем розгорнуто психологічний простір людини, у якому змішуються риси реальності й нереальності. Уже 3 перших рядків автор наголошує на внутрішніх станах героїні, 3-поміж яких переважає постійний страх: Їй здавалося, що страх - то маленький волохатий чоловічок, який живе в ї̈ душі й перелякано б'ється в ній, коли на неї починає насуплено дивитися чи кричати чоловік [Габор 2009: 91]. Зрештою iï страх стає таким великим, що з маленького волохатого чоловічка перетворюється на образ звіра, який мерещиться їй скрізь: у гіллі горіха, здалося їй, сидить звір і дивиться на неї холодними очима, хижо посміхаючись, $і$ ніби каже їй, що вона нікуди від нього не втече; попід вікнами ї̈ палати, навколо їхньої хати все нагадував про себе то рипом дошки, то стуком, то хруском переламаної гілки [Габор 2009: 91]. Отже, образ звіра проєктується на образ страху героїні: страх — це звір, який сидить у ній самій. Крім того, Марія так боїться свого чоловіка Миколу, який постійно знущається над нею, що й він стає для неї уособленням звіра, а в одній з характеристик його односельцями зазначено: Та то не чоловік, а звір [Габор 2009: 94]. Тож образ звіра домінує у творі й перетворюється на багатозначний символ: він постає у двох площинах зображення - звір реальний і звір уявний. Це й визначає символічний зміст назви новели. У кульмінаційному моменті твору — зображенні смерті головної героїні - яскраво виявляється чи не найхарактерніший образ експресіонізму: Вона померла в темній кімнаті в страшну бурю, яка вивернула з корінням горіх $і$ кинула його між хатою і хлівом на городець. Микола не ночував вдома. Застав ї̈ вранщі зачіплену в ліжку з виряченими очима і відкритим ротом. Ні рот, ні очі не змогли стулити [...] [Габор 2009: 94].

Така сама нервова емоційність притаманна й новелі Швони. Автор фіксує кожен внутрішній і зовнішній порухи головного героя Івана Швонца: Він то сідав на стілеиь, то схоплювався з нього; рвучко повернувся до матері [Габор 2009: 76]; щосили огрів батогом коней; зло блимнув чорними очима 
на матір; глухо застогнав, зубами заскрипів [Габор 2009: 77]. Знервованість сина не лишається поза увагою матері й спричинює їі переживання, емоційні стани тривоги й страху, останній з яких переважає: Швонцова мати втратила спокій; розтривожилася, і великий страх напав на неї за сина [Габор 2009: 81]. Страх героїні зумовлений не лише поведінкою сина, але й трагічними передчуттями біди. Особливого значення набуває оніричний хронотоп, який органічно вписується в семантичний простір новели. Зауважмо, що в багатьох творах В. Габора дія відбувається на рівні взаємодії сну й дійсності. За словами самого письменника, „у Книзі екзотичних снів та реальних nодій все перемішано. І важко зрозуміти, де реальність, а де сон" [Габор 2010: 110]. Страшний сон матері, від якого вона прокинулася мокра від поту, від страху зуб на зуб їй не потрапляв. Сполоханою птахою билося ї̈ серие [Габор 2009: 82] і від якого їй ще й тепер було моторошно [Габор 2009: 81], стає пророчим й ототожнюється з реальними подіями. У сні мати побачила те, що потім наяву сталося 3 iï сином: його зарізали на весіллі. Убивство героя зображено насамперед реалістично: Били, итрикали ножами у спину, груди [...] [Габор 2009: 82], а потім увиразнено метафорою а біля ї сина все танцювали з кривавими ножами шандрівські легіні [Габор 2009: 82], що є своєрідною трансформацією загальновідомого сюжету Танець смерті, розповсюдженого в західноєвропейській культурі, починаючи ще із часів середньовіччя, i втіленого в різних видах мистецтва, насамперед образотворчого, де він набув значення жанру.

Трагічне передчуття матері, що нагнітається, відтінене колористичними деталями 3 домінуванням червоного кольору: червона вода; біла, як сніг сорочка почервоніла; криваві ножі [Габор 2009: 81]. Опозиція білий - червоний проєктується на протиставлення життя - смерть. Ключовий образ червоної води, що виникає вві сні героїні, у реальності перетворюється на криваву воду річки - i раптом Швонииха заціпеніла: згори текла закривавлена вода [Габор 2009: 83]. Отже, міфологема води всупереч загальноприйнятому вітаїстичному змісту набуває мортальної символіки. Загалом усі образисимволи й художні деталі у творі підпорядковані зображенню трагічної реальності й часто позначені амбівалентністю. Напр., якщо в новелі Щоб не бив бубон гупання бубна на вулиці - символ страшної події, то в новелі Швонц - навпаки: мовчання бубна на весіллі свідчить про те, що сталася трагедія.

Поминки - містично-реалістична новела. Сюжет твору простий лише на перший погляд, але цілком реалістичний: в однієї жінки помер чоловік, і вона серед ночі приходить запросити головну героїню за старшу кухарку на поминках, на що та, хоч і сумнівається, але погоджується, - i це рішення призводить їі до смерті. Письменник зображує реальну дійсність, у яку втручається щось надприродне. Новела окутана містикою з перших рядків (Вже ввечері, коли вклалася спати, до неї постукали. [...]. На танку стояла жінка в чорній одежі [Габор 2009: 149]) і до останніх (І з нею трапилося так, як з покійним, 
коли привиділося їй, як він піднявся в труні і випив, 一 відтак все огорнула суиільна темрява. [...]. Ї̈ віз повільно котився в чорну безодню ночі [Габор 2009: 149]). Із самого початку виникає таємниця, на якій тримається сюжет. Після приходу жінки в чорному й до моменту смерті героїня чує голос, що видається їй знайомим, але вона не може пригадати, чий він. Голос застерігає iii не йти куховарити, а на поминках — не пити. Завдяки такому зображенню відбувається перенесення в паралельний вимір буття (ірреальний), а сама героїня знаходиться на роздоріжжі - між реальним і містичним. Містика дає можливість зануритися у свідомість героїні, збагнути ії сутність, з'ясувати мотивацію іiі поведінки і вчинків. Напр., незважаючи на попередження таємничого голосу, вона все ж вирішує прийняти запрошення, оскільки вважає, що не по-християнськи відмовляти людині, коли вона в біді [Габор 2009: 149], а вже на поминках думає, щзо від надмірної напруги і духоти біля грубки усе uе їй примарюється [Габор 2009: 151]. Отже, містичне сприяє загостренню сюжету, створює ефект напруги й призводить до несподіваного фіналу.

У новелі Поминки простежуємо взаємопроникнення романтичної й реалістичної естетики. Органічне поєднання містичного й реального дає підстави говорити про риси фантастичного реалізму 3 акцентом на таємничому (як у романтиків) і на реальному (як у реалістів). Відразу зауважмо, що, використовуючи термін фантастичний реалізм, ми не ототожнюємо його 3 магічним реалізмом, хоча вони обидва й полягають в органічному поєднанні реалістичних та фантастичних рис, але зміст цього фантастичного різний. Воснові магічного реалізму взаємопереплетення реалістичного, міфологічного та релігійного світоглядів, а фантастичний реалізм базується на сполученні реального з містичним, потойбічним (саме в такому руслі написана новела Поминки). Магічний реалізм теж наявний у творчості письменника, що дає змогу виокремити магічну новелу. Загалом чимало новел Книги екзотичних снів та реальних подій В. Габора позначені боротьбою двох тенденцій: реалістичної й фантастичної - звідси назва збірки.

У кожній новелі, як бачимо, кількість зображених персонажів нечисленна, але розвиток сюжету і його напруження досягаються завдяки художньому відтворенню емоційних станів героїв, передаванню найменших порухів людських почуттів і настроїв. Як наслідок у всіх творах письменника виявляється яскраво виражений елемент традиційного новелістичного жанру - поглиблений психологізм, що реалізується за допомогою різних засобів, панівними серед яких $є$ використання психологічних деталей, прийому сну, внутрішніх монологів тощо.

Крім того, у розглянутих новелах В. Габора згідно з класичною новелістичною традицією важливе місце займає категорія смерті з різним її зображенням: якщо в новелі Щоб не бив бубон самогубство героїні можна розглядати крізь призму експресіонізму, то в новелі Звір маємо абсолютно 
експресіоністичне зображення смерті; якщо в новелі Швони смерть героя показана реалістично з використанням метафори-алюзії для підсилення емоцій від ії сприйняття, то в новелі Поминки смерть героїні цілком проникнута таємницею в дусі романтизму.

Зовсім іншу манеру письма простежуємо в новелах збірки Про що думає людина. У центрі зображення в текстах творів не сам предмет, а враження від нього й ті асоціації, які він викликає, уривчасті фрагменти, відбиті у свідомості автора, наявність психологічного часу, що складається з пам'яті, відчуттів, переживань. Часопростір часто ущільнюється до маленької вулички, будинку, кімнати (напр., Світ людини в кімнаті), а увага концентрується на найдрібніших деталях, що збуджують забуті емоції й допомагають у малому знайти велике. Усе це наближає В. Габора до естетики імпресіонізму.

У новелі Про що думає людина, йдучи на роботу письменник передає миттєві враження від споглядання довкілля: дерева за вікном (Дивлячись на нього, завжди відчуваєш спокій на душі [Габор 2012: 9]), закарбовує в пам'яті всі зміни, що відбуваються в природі (Щодня каштан має інший вигляд: весною приворожує бруньками, які поволі розпускаються; восени милуєшся жовтим листям; а взимку, як лапатий сніг вкриває гілля [Габор 2012: 9]), фіксує свої думки про сумні речі, про те, що приносить приємність і спогади про світ дитинства [Габор 2012: 10].

Уособленням світу дитинства для письменника $є$ образ саду, майстерно виписаний у дусі імпресіонізму, де кожна метафора - ніби мазок пензля: Коли він заивітав, то здавалося, що береги вкривав біло-рожевий сніг. Це було справжне море теплого ивіту [Габор 2012: 11]. Та раптом таке зображення саду переходить в експресіоністичний новелістичний сюжет, що закінчується смертю людини: На третій день його знайшли бездиханного на старій яблуні. Вітер тихо гойдав його застигле тіло, і тільки носики черевиків ледь черкали об сніг [Габор 2012: 11]. Образ саду набуває мортальної семантики: тепло змінюється холодом (передано метафорично через опозицію море теплого иввіту - холодне море снігу), радість - смутком, життя - смертю.

На людське життя й саму людину спроєктовано образ дерева, що помирає. Це дерева на каштановій алеї, деякі з яких покалічені бурями, деякі з безжально обпиляними стовбурами, немов з обрубаними руками, деякі з великими замурованими цеглою дуплами. I щороку дерев стає менше - вони помирають непомітно, як люди [Габор 2012: 12]. Це й велетенська тополя, яку зламала буря, залишивши лише гнилий пень [Габор 2012: 13]. Невипадково новела закінчується риторичним запитанням: Невже $і$ ми, як ті дерева, так само ненадовго залишаємося жити в чиїйс пам'яті? [Габор 2012: 13], що звучить по-філософськи й наштовхує читача на роздуми.

Подібну побудову має й новела Світ людини біля будинку, у якій враження, асоціації (дерева - вартові хати, ворота - щит обійстя, піч - казка, вули- 
ия - свято, вогонь - цичанки в квітчастих спідницях тощо), спогади 3 дитинства переростають у новелістичний сюжет про молоду циганку, яка ніби приворожила малого хлопця, і той з легкістю віддав їй усі гроші, які мама залишила, щоб купив хліба [Габор 2012: 25], що потім послідовно переходить у наступний, як сільські жінки врятували на вулиці п'яного чоловіка [Габор 2012: 25]. Завершується твір ланцюжком асоціацій: дзвін - голос людської душі, грім - страх для одних дітей, а для інших — ніби музика небес [Габор 2012: 25]; вітер - мандрівна душа; ие роки, щзо минають безслідно; шум листя в кронах дерев; тихе гупання яблук у садку [Габор 2012: 26].

У текстах цієї збірки також наявне поєднання реального та ірреального, як у новелі Шандрово та його духи, де крізь призму світогляду дитини постає світ, у якому тісно перепліталися різні дива й фантазії, добрі і злі духи [Габор 2012: 63]; і зображення трагічних подій із життя євреїв Шандрова, звідки родом В. Габор (новела Густі юдейські ночі); і спогади письменника про важливі для нього події (Історія про один долар) й особливих людей (новели Бешкетний сміх джазу, В мене так гарно розпочалося літо, Ах Юрик кирюха та ін.), і тривожні передчуття (Сон у сні).

Як бачимо, у новелах збірки Про щчо думає людина яскраво окреслюються основні ознаки сучасної модифікованої новели, коли внутрішня дія стає головною й на перший план виходять поглиблена асоціативність, метафоричність, образність. За словами В. Неборака, В. Габор „не ставить собі за мету здивувати читача експериментами 3 формою і змістом”, але ,його проза - і вишукана, і різноманітна" [Неборак 2018]. У цьому й виявляється новаторство новелістики В. Габора.

Отже, творчості В. Габора притаманні жанрово-стильові пошуки. Новелістика письменника, репрезентована збірками Книга екзотичних снів та реальних подій та Про що думає людина, різнопланова, характеризується й традиціями, і новаторством. Прозаїк розвиває жанр у руслі класичної новели й водночас експериментує. За канонами новелістичного жанру в основі багатьох його творів наявність незвичайної події з несподіваним фіналом, сюжетна однолінійність, коли кількість персонажів зведена до мінімуму, поглиблений психологізм і важлива функціональна роль художньої деталі. Новаторство полягає в оновленні не лише форми, але й змісту новели.

Новелістика В. Габора позначена синкретизмом. Творчий метод письменника не можна втиснути в єдину стильову систему. Насамперед новели письменника органічно вписуються в контекст модерністської естетики: простежується їхня спорідненість з новелістикою В. Стефаника та М. Коцюбинського. 3 одного боку, вони вирізняються стефаниківським загостреним драматизмом і лаконізмом, коли вилучено все несуттєве, а залишено лише явища й факти. Такими є новели Щоб не бив бубон, Звір, Швони, у яких реалізується головна дилема експресіонізму - протистояння життя й смерті, трагедійність 
світовідчуття. 3 другого, позначені імпресіоністичними традиціями М. Коцюбинського, прикладом чого слугують новели збірки Про що думає людина. Крім того, складниками стилю В. Габора $є$ і реалізм, і романтизм, поєднання яких стає основою фантастичного реалізму, у дусі якого написано проаналізовану авторкою новелу Поминки.

Очевидно, розгляд новелістики В. Габора в окресленому аспекті неможливо вичерпати рамками однієї статті, що зумовлює подальші напрями наших досліджень.

\section{Список використаної літератури}

Горнятко-Шумилович А., $У$ „холодних потоках нез'ясованості”. На перетині художніх світів новел Хуліо Кортасара й Василя Габора, [в:] „Studia Ukrainica Poznaniensia”, zesz. II, 2014, s. 39-49.

Мельник Н., Проникнення в іншу реальність: (українська магічна новела наприкінці XX cm.), [в:] „Слово і час”, 1998, № 11, с. 46-51.

Неборак В., Про щзо думає Василь Габор, [в:] Електронний ресурс: https://zbruc.eu/ node/16442 (20.12.2018).

Погорецький В., Тривоги думання: критика, рецензї, огляди, літературні новини, [в:] Електронний ресурс: http://zolotapektoral.te.ua/tryvohy-dumannya/ (20.12.2018).

Слободян Н., Класична новела Василя Габора, [в:] Постуn, 1999, ч. 108, с. 8-18.

Таран Л., Василь Габор: Людині легко побороти чорнузаздрість, [в:] Електронний ресурс: https://life.pravda.com.ua/society/2013/04/22/126469/ (19.12.2018).

\section{Spysok vykorystanoi literatury [References]}

Horniatko-Shumylovych A., $U$,,kholodnykh potokakh neziasovanosti”. Na peretyni khudozhnikh svitiv novel Khulio Kortasara y Vasylia Gabora [In the „Cold Streams of Obscurity”. In Between Artistic Worlds of Julio Cortazar and Vasil Gabor Novels], [v:] „Studia Ukrainica Poznaniensia”, zesz. II, 2014, s. 39-49.

Melnyk N., Pronyknennia $v$ inshu realnist: (ukrainska mahichna novela naprykintsi XX st.) [Into Another Reality: (Ukrainian Magic Novel at the End of the XX Century)], [v:] „Slovo i chas”, 1998, № 11, s. 46-51.

Neborak V., Pro shcho dumaie Vasyl Gabor [What does Vasyl Gabor Think About], [v:] Elektronnyi resurs: https://zbruc.eu/node/16442 (20.12.2018).

Pohoretskyi V., Tryvohy dumannia: krytyka, retsenzii, ohliady, literaturni novyny [The Worries of Thinking: Critique, Reviews, Surveys, Literature News], [v:] Elektronnyi resurs: http:// zolotapektoral.te.ua/tryvohy-dumannya/ (20.12.2018).

Slobodian N., Klasychna novela Vasylia Habora [Vasyl Gabor's Classic Novel], [v:] Postup, 1999, ch. 108, s. 8-18. 
Taran L., Vasyl Gabor: Liudyni lehko poboroty chornu zazdrist [Vasyl Gabor: It's Easy for a Human to Overcome Vile Envy], [v:] Elektronnyi resurs: https://life.pravda.com.ua/ society/2013/04/22/126469/ (19.12.2018).

\section{Список використаних джерел}

Габор В., Книга екзотичних снів та реальних подій, Львів: ЛА „Піраміда”, 2009.

Габор В., Від Джойса до Чубая. Есеї, літературні розвідки та інтерв'ю, Львів: ЛА „Піраміда", 2010.

Габор В., Про щео думає людина: Візї та невигадані історії, Львів: ЛА „Піраміда”, 2012. Культура Японіï, [в:] Електронний ресурс: http://happyhikaroblog.blogspot.com/2016/04/ blog-post.html (09.01.2019).

\section{Spysok vykorystanykh dzherel}

Gabor V., Knyha ekzotychnykh sniv ta realnykh podii [The Book About Exotic Dreams and Real Events], Lviv: LA „Piramida”, 2009.

Gabor V., Vid Dzhoisa do Chubaia. Esei, literaturni rozvidky ta interviu [From Joyce to Chubay. Essays, Literature Research and Interviews], Lviv: LA „Piramida”, 2010.

Gabor V., Pro shcho dumaie liudyna [What does the Human Think About], Lviv: LA „Piramida”, 2012.

Kultura Yaponii [Culture of Japan], [v:] Elektronnyi resurs: http://happyhikaroblog.blogspot. com/2016/04/blog-post.html (09.01.2019). 